\title{
Epidemiology of Retinoblastoma
}

\author{
Wilson O. Akhiwu ${ }^{1}$ and Alex P. Igbe ${ }^{2}$ \\ ${ }^{1}$ Histopathology Department, University of Benin Teaching Hospital, \\ Benin City, Edo State \\ ${ }^{2}$ Histopathology Department, Ambrose Alli University Ekpoma, Edo State \\ Nigeria
}

\section{Introduction}

It is widely acknowledged that cancers are disorders of cell growth and behavior and that its cause has to be defined at cellular levels. However, studies have shown that the cause of cancer can be deduced from a study of its epidemiology. Sir Percival Pott is credited with linking chemicals to causing cancer when he observed astutely that Chimney sweeps, because of their chronic exposure to sooth, were prone to scrotal cancers. Subsequently, the Danish Chimney sweeps guild ruled that its members must have their bath daily and this prevented the problem. ${ }^{1}$ Prior to this, John Hill had linked nasal polyps to "immoderate use of snuff". Epidemiology has also contributed in linking cervical cancer to human papilloma viruses and radiation to different cancers ${ }^{1}$. It is also important for the purposes of health planning and allocation of resources to know the distribution of any particular disease.

Retinoblastoma, an embryonal tumour originating from retinal cells, is reputed to be the commonest intraocular malignancy in children. Currently, retinoblastoma is the most common solid tumour in children after brain/nervous system tumours and lymphomas in the United Kingdom. ${ }^{2}$ Kramarova and Stiller also reported a similar pattern among American children. ${ }^{3}$ In Nigeria, retinoblastoma is second only to lymphoma in most studies $^{4,5,6}$ and third in some series. ${ }^{7}$ Report from other African countries shows that this tumour is the second most common childhood solid tumour. ${ }^{8}$

\section{Age distribution}

Age has an important influence on the likelihood of beings afflicted with cancer. The incidence of cancer rises with advancing age and most cases occur in people aged 55years and above. The age related rising incidence may be explained by the accumulation of mutations associated with the emergence of cancers. Most cases of retinoblastoma, however, occur in childhood with over $90 \%$ being diagnosed before five years of age; only 24 cases have been reported in adults aged between 20 years and 74 years. ${ }^{9}$ The worldwide incidence rate of retinoblastoma for children aged 0-4years varies from $3.4 \%$ per million in Bulgaria10 to a very high 42.5 per million in Mali.11 Incidence rates vary greatly in some regions while it varies only slightly in some other regions (table 1). 


\begin{tabular}{|c|c|}
\hline Region & Incidence \\
\hline Australia & 1.4 \\
\hline Belgium & 1 \\
\hline Canada & 2 \\
\hline Croatia & 0.7 \\
\hline Czech Republic & 0.7 \\
\hline Denmark & 1.3 \\
\hline Estonia & 1.5 \\
\hline Finland & 1.1 \\
\hline France & 1.6 \\
\hline Germany & 2.3 \\
\hline 1celand & 1.1 \\
\hline Ireland & 1.0 \\
\hline Italy & 1.4 \\
\hline Latvia & 0.2 \\
\hline Lithuania & 1.4 \\
\hline Malta & 1.9 \\
\hline New Zealand & 2.2 \\
\hline Norway & 0.7 \\
\hline Poland & 0.6 \\
\hline Portugal & 3.6 \\
\hline Russia & 1.3 \\
\hline Slovakia & 1.5 \\
\hline Slovenia & 1.0 \\
\hline Sweden & 3.5 \\
\hline Switzerland & 1.7 \\
\hline The Netherlands & 1.2 \\
\hline United Kingdom & 1.3 \\
\hline United States White & 1.4 \\
\hline United States Hispanic & 1.4 \\
\hline Yugoslavia & 0.2 \\
\hline
\end{tabular}

Table 1. Average incidence for whites in the United States and Nations with greater than 85\% White population (adapted from J Pediatr Ophthalmol Strabismus 2009 ;46: 288-293)

A large study in the USA ${ }^{12}$ covering a 30year period from1975 - 2004 using the Surveillance Epidemiology and End Results (SEER) programme database of the National Cancer Institute found 658 of retinoblastoma cases over the period. The overall mean 
adjusted incidence was 11.3 for males and 12.4 for females. Seventy two per cent $(72 \%)$ were unilateral while $27 \%$ were bilateral. In $1 \%$ of cases the laterality was unknown. With increasing age at diagnosis, the bilateral tumours decreased significantly. However, the percentage of unilateral tumours increased with increasing age at diagnosis. The overall incidence of retinoblastoma also reduced with increasing age (Figure 1). Bilateral new cases are not seen after the age of 3years. The peak age of presentation for both bilateral and unilateral retinoblastoma in the USA is before one year of age. Thereafter, the incidence reduced steeply with age. Only $4.3 \%$ of new cases of retinoblastoma were seen between the ages of 5-9years in this study.

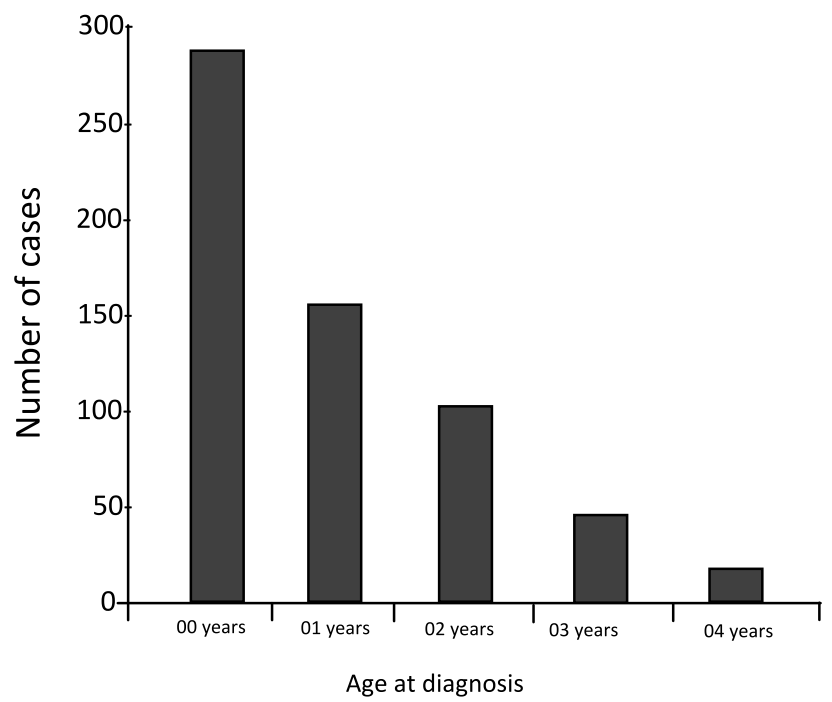

Fig. 1. Distribution of retinoblastoma by age at diagnosis (Adapted from Br J Ophthalmol 2009; 93: 21-23)

Another work in the USA ${ }^{13}$ from 1993 to 1997 using data from the international agency for cancer found a rate incidence of 4.4 per million for white children with most of the other findings similar to the findings by Broaddus et al. ${ }^{12}$

In Great Britain,14 retinoblastoma affects approximately 1 in 20000 children. The bilateral cases make up 36\% of the total cases. In this study in the UK, using the National Registry for Childhood Tumours (NRCT), the peak incidence was in children below one year, similar to findings in USA studies. After the age of one year, the incidence reduced steadily. Children older than four years made up less than $5 \%$ of new cases. The peak age for unilateral cases is in the two year age group while that of bilateral cases is before the first birthday. British studies have shown that unilaterality does not rule out heredity. In this series reported by MacCarthy et al, almost $11 \%$ of the unilateral retinoblastoma was heritable cases. All the bilateral cases are usually heritable.

A Swedish and Finish ${ }^{15}$ study covering 1958 to 1998 using data from cancer registries and corresponding national referral centers for retinoblastoma found 0-13 and 0-10 new cases per year in Sweden and Finland respectively. The incidence rates per million children under 
5years in Sweden and Finland was 11.8 and 11.2 respectively. In this study $90-96 \%$ of all retinoblastomas were diagnosed in children less than 5 years.

In Pakistani studies, 16 between 1999 and 2002 found 70 retinoblastoma cases, with $93 \%$ of them in children below 5years; $67 \%$ of the cases were bilateral. Bilateral cases became less prevalent with increasing age while the unilateral cases peaked in the 2-3year age group with a gradual decline thereafter. The mean at presentation is 28.17 months, unilateral cases having a mean age of 31.81 months. In China,17 a study covering 1957 to 2006 found that 1234 eyes were enucleated due to retinoblastoma in a specialist eye hospital. The mean age was $2.8 y e a r s$ with a range of 1 month to 14 years. Bilateral tumours accounted $2.4 \%$ of cases, an interesting finding. This was attributed to the nature of their study.

In South Africa, 18 a study by Freedman and Goldberg in 1976 covering a 20-year period in a specialist eye Hospital found 71 cases out of which $82 \%$ were unilateral and the other $18 \%$ bilateral. The average of the unilateral cases was $3 \frac{1}{2}$ years while while for the bilateral, it was 3years, much higher than the findings in western industrialized countries; $80 \%$ of cases were diagnosed before the age of 4years.

In a Congolese ${ }^{19}$ study carried out in a teaching Hospital on Congolese blacks over a 58 month period found $21 \%$ bilateral cases. The mean age for all cases was $2.94 y e a r s$ with a 4 months to 6years. The mean age for the bilateral cases was 1.12 years. The mean age in other African studies ranged from 24 months to 44 months. ${ }^{20,21,22,23}$ The relatively advanced age of presentation in African series has been attributed very late presentation. The African patients may seek alternative means of healing before coming to hospital. Incidence studies in Africa put the incidence estimates at 20 cases per million in Malawi24 and 9.3 per million in Guinea Conakry. ${ }^{25}$ These are much higher than rates in USA. This has been attributed to some unknown environmental influences and the higher birth rates in Africa.

In Nigeria, retinoblastoma is the commonest childhood intraocular malignancy with a mean age at presentation of 29 months. For bilateral retinoblastoma which accounted for $13 \%$ of cases, the mean age at presentation was younger at 15 months. ${ }^{26}$

\section{Sex distribution}

Most studies from different parts of the world suggest no sex discrepancy in the incidence of retinoblastoma. In the USA, studies by different workers ${ }^{12,13}$ have found an age adjusted incidence of 11.3 for males and 12.4 for females suggesting a mild female predominance. This difference however was not significant.

In Mexico, ${ }^{27}$ a study carried out in sixteen centers over a 5-year period showed a non significant mild male predominance of 1.1: 1.0 for all the cases seen. These studies do not show any breakdown of the sex distribution between the age groups and between the unilateral, bilateral and other types of retinoblastoma.

In Great Britain, the study by MacCarthy et al ${ }^{14}$ showed that overall, males and females had no difference in the distribution of retinoblastoma for all ages. However, for the 0-1year age group in bilateral retinoblastoma category, there is a 1.1: 1.0 male predominance. For the 1-2 year age group, the male: female predominance for the bilateral tumours is 1.3: 1.0 while for 
the 2-3year age group, it is 2.2: 1.0. All other age groups showed no significant M:F difference in the incidence of bilateral retinoblastoma. For bilateral tumours for all ages, the M:F ratio 1.3: 1.0.

In Pakistan, Arif Mohamed et al16 found an equal sex distribution for retinoblastomas in childhood. There was also no gender difference between the unilateral and the bilateral cases.

In China,17 between the years 1977 to 1996, there was a marked male predominance of 3: 2 and an insignificant overall male predominance of 2.6: 2.0. As in many other studies, the sex distribution between the unilateral and bilateral tumours is not stated.

In Southern Africa studies, ${ }^{18}$ there is a marked male predominance over females (3:1) in the bilateral cases. However, for the unilateral cases, the ratio of males to females is 1.2: 1.0. For the1-2year age group, the M: F ratio is about 2: 1 . Overall however the M: F ratio is 4:3.

Studies from Congo ${ }^{19}$ show a M: F predominance for all cases of retinoblastoma seen over a $6 y e a r$ period to be 2:1. Some other African studies show a male: female ratio of 1.120,21

In Ilorin, Nigeria, ${ }^{26}$ there was a mild female predominance of 1.2: 1 overall. The mean age for females and males was also not significant at 31 months and 27 months respectively. However, Akang et $a^{20}$ from Ibadan, Nigeria reported a female predominance of 3:2.

\section{Geographical/racial distribution}

Retinoblastoma has a worldwide distribution. It has been reported from different parts of the world. Because the pathogenesis of retinoblastoma is linked with genetic alterations in the tumour suppressor $\mathrm{Rb}$ gene on chromosome 13q14, one would expect a racial variation.

A study by Krishna et al28 covering a 7year period between 1993 and 1997 and using data from International agency for Research on Cancer, a comparison of the racial and geographic incidence patterns of retinoblastoma in North America, South America, Oceania and Eroupe was carried out. This, to our knowledge, is the most comprehensive that attempts to find a racial and geographic pattern in the incidence of retinoblastomas. This work found a higher incidence of retinoblastoma in Hispanics in the USA than in white children in 3 areas- Los Angeles, San Francisco and New Mexico. However, when adjustments were made and comparison with White population was made, there was no significant difference. This was interpreted to mean that retinoblastoma was similar in White and Hispanic populations in the United States. However, Pendergrass and Davis 12 and Howe et $\mathrm{al}^{29}$ had found higher rates in Hispanic population over the White population. The consensus, however, is that the perceived difference can be attributed to confounding factors such as cancer registration practices or number of cases. In this study, the rate of retinoblastoma in whites in Europe was found to be the same as in Whites in USA. There was also no significant difference in the incidence in White populations in Oceania and USA. It was only the rates in Portugal and Sweden that were significantly higher than rates in the US Whites. This was attributed to cancer reporting practices ${ }^{30}$. The rates in Canada were similar to that in USA. The Broaddus et al study ${ }^{12}$ in USA also showed no significant difference between Whites and Blacks in the USA. 
Comparing the incidence of retinoblastoma in Africans with that of other advanced countries is difficult because calculating rates in Africans countries is fraught with problems. However, rates of up to 20 per million children under five 249.3 per million age standardized in Guinea Conakry 25 have been noted. These would suggest that the rates are much higher in Africa than the rest of the world. This has been attributed to ignorance, poor health facilities and high birth rates. What, however, is certain is that African retinoblastomas are diagnosed at a significantly later age than in the advanced world.

\section{Summary}

Retinoblastoma is a childhood cancer with $90 \%$ diagnosed before the age five years. Only 24 cases have been reported in adults between 20-74 years worldwide. Unilateral cases are commoner than bilateral cases in a ratio of $2.7: 1$. With increasing age at diagnosis, unilateral cases increased significantly while the bilateral cases decreased significantly. However, the overall incidence of retinoblastoma decreases with advancing age. The peak age of presentation is before the age of one year in advanced countries but between the ages of two and three years in Africa due to late presentation. Although many studies show a mild female predominance, this is not significant. However, some European studies note a significant male predominance for bilateral tumours and retinoblastoma diagnosed in the two to three year age group.

The incidence rate varies worldwide with higher levels in Africa and much lower levels in Europe. However, in multiracial countries like the USA, no significant difference between races was found

\section{References}

[1] Cotran R S, Kumar V, Collins T (eds). Robbins Pathologic Basis of disease (7th edn). Philadelphia, W B Saunders, 2004; pp 269-342.

[2] Sharp L, Gould A, Harris V, et al. United Kingdom Scottish Cancer Registry 1981- 1990. In Parkin D M, Kramarova E, Drapper G J, et al (eds). International Incidence of Childhood Cancer (Vol 2). IARC Sci Publ No 144, Lyon, 369-371.

[3] Bunin GR, Jarreti P, Meadows AT. Greater Delaware Valley Paediatric Tumour Registry, 1970-1979: in Parkin D M, Stiller CA, Drapper GJ et al . (eds). International Incidence of Childhood Cancer. IARC Sci Publ No 87, Lyon, 1988, 81-86.

[4] Akang EEU. Childhood Tumours in Ibadan, Nigeria (1973-1990). Paediatric Pathology and Laboratory Medicine, 1996; 16: 791-800.

[5] Mandong BM, Angyo IA, Zoakah AI. Paediatric Solid Malignant Tumours in JUTH, Jos, (Hospital based histopathological study) Nig J Med, 2000; 9(2): 52-55.

[6] Tijani SO, Elesha SO, Bayo AA. Morpliological patterns of paediatric solid cancer in Lagos, Nigeria. West Afr J Med. 1995; 14(3): 174 - 179.

[7] Akhiwu WO, Igbe AP, Aligbe JU, Eze GI, Akang EEU. Malignant Childhood Tumours in Benin City. West Afr J Med 2009, 28(4): 222-226.

[8] Welbeck JE, Hesse AA. Pattern of childhood malignancy in Korle Bu Teaching Hospital, Ghana. West Afr. Med. J. 1998; 17(2) 81-4. 
[9] Singh SK, Das D, Bhahattacharjee $\mathrm{H}$, et al. A rare case of adult onset retinoblastoma. Oman J Ophthalmol 2011; 4(1): 25-27

[10] Bunin GR, Orjuela M. Geographic and environmental factors. In Singh AD, Damato BE Pe'er j, et al, eds. Clinical ophthalmic oncology. Philadelphia: Saunders-Elsevier, 2007: 410-16

[11] Parkin DM, Kramarova E, Drapper GJ et al. International incidence of childhood cancer, vol II. IARC Sci Publ 1998: 1-391

[12] Broaddus E, Topham A, Sigh AD. Incidence of retinoblastoma in the USA: 1975-2004. Br J Ophthalmol 2009; 93:21-23

[13] Pendagrass TW, Davis S. Incidence of retinoblastoma in the United States. Arch Ophthalmol 1980; 98: 1204-10

[14] MacCarthy A, Birch JM, Drapper GJ, et al. Retinoblastoma in Great Britain 1963-2002. Br J Ophthalmol 2009; 93: 33-37

[15] Seregard S, Lundell G, Svedberg H, Kivela T. Incidence of retinoblastoma from 1958 to 1998 in Northern Europe. Ophthalmol 2004;111: 1228-1232

[16] Arif M, Iqbal Z, Islam Z. Retinoblastoma in NWFP, Pakistan. J Ayub Med Coll Abbottabad 2009; 21(4): 60-62

[17] Bai S, Ren R, Shi J, et al. Retinoblastoma in the Beijing Tongren Hospital from 1957 to 2006: clinicopathological findings. Br J Ophthalmol (2010). doi:10.1136/bjo.2010.181396

[18] Freedman J, Goldberg L. Incidence of retinoblastoma in Bantu South Africa. Br J Ophthalmol 1976; 60: 655-56

[19] Kaimbo Wa Kaimbo D, Mvitu MN, Missotten L. Presenting signs of retinoblastoma in Congolese Patients. Bull Soc Belge Ophthalmol 2002; 283: 37-41

[20] Akang EE, Ajaiyeba IA, Campbell OB, Olurin IO, Aghadiuno PU. Retinoblastomas in Ibadan Nigeria-II: Clinicopathologic features. West Afr J Med 2000: 19: 6-11

[21] Chantada G, Fandino A, Manzitti J, Urutia L, Schvertzman E. Late diagnosis of retinoblastoma in a developing country. Arch Dis Child 1999; 80: 171-4

[22] Kayembe L. Retinoblastoma- 21years review. J Fr Ophthalmol 1986; 9: 651- 5

[23] Nwosu SN, Okoye GS, Ulasi TO. Delayed diagnosis of retinoblastoma. Cent Afr Med J. 1994; 40: 353-55

[24] Ben ED, Chirambo MC. Incidence of retinoblastoma in Malawi. Pediatr Ophthalmol 1976; 13: 340-43

[25] Koulibaly M, Kabba IS, Cisse A, et al. Cancer incidence in Conakry, Guinea: First results from the cancer registry 1992-1995. Int J Cancer1997; 70: 30-45

[26] Owoeye JFA, Afolayan EAO, Ademola-Popoola DS. Retinoblastoma - a clinicopathologic study in Ilorin Nigeria. Afr J Health Sci 2005; 12(3-4): 94-100

[27] Lea-Leal C, Flores-Rojo M, Medina-Samson A, et al. A multicentre report from the Mexican retinoblastoma group. Br J Ophthalmol 2004; 88: 1074-1077.

[28] Krishna SM, Yu G, Finger PT. The effect of race on retinoblastoma. J Pediatr Ophthalmol Strabismus 2009; 46 (5): 288-293.

[29] Howe HL, Wu X, Ries LA, et al. Annual report to the nation on the status of cancer, 1975-2003, featuring cancer among US Hispanic/Latino populations. Cancer 2006; 107:1711-1742 
[30] Steliarova-Foucher E, Stiller C, Kaarsch P, et al. Geographical patterns and time trends of cancer incidence and survival among children and adolescents in Europe since the 1970s (the AC-CIS project): an epidemiological study. Lancet 2004; 364: 20972105 


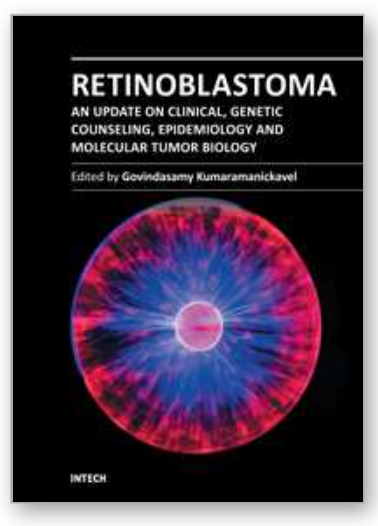

\author{
Retinoblastoma: An Update on Clinical, Genetic Counseling, \\ Epidemiology and Molecular Tumor Biology \\ Edited by Prof. Govindasamy Kumaramanickavel
}

ISBN 978-953-51-0435-3

Hard cover, 170 pages

Publisher InTech

Published online 28, March, 2012

Published in print edition March, 2012

Retinoblastoma is the first tumor suppressor gene discovered ever. The discovery opened a new avenue in the field of oncology leading to the identification of 35 tumor suppressor genes, till date in our genome. This book is an excellent compilation of both clinical and basic science information that meets the needs of a young clinician and a researcher at the same time. It also has abundant information on recent advances and cuttingedge knowledge in intracellular molecular cross-talking of retinoblastoma protein with various cellular viral-like proteins.

\title{
How to reference
}

In order to correctly reference this scholarly work, feel free to copy and paste the following:

Wilson O. Akhiwu and Alex P. Igbe (2012). Epidemiology of Retinoblastoma, Retinoblastoma: An Update on Clinical, Genetic Counseling, Epidemiology and Molecular Tumor Biology, Prof. Govindasamy Kumaramanickavel (Ed.), ISBN: 978-953-51-0435-3, InTech, Available from:

http://www.intechopen.com/books/retinoblastoma-an-update-on-clinical-genetic-counseling-epidemiology-andmolecular-tumor-biology/epidemiology-of-retinoblastoma

\section{INTECH}

open science | open minds

\section{InTech Europe}

University Campus STeP Ri

Slavka Krautzeka 83/A

51000 Rijeka, Croatia

Phone: +385 (51) 770447

Fax: +385 (51) 686166

www.intechopen.com

\section{InTech China}

Unit 405, Office Block, Hotel Equatorial Shanghai

No.65, Yan An Road (West), Shanghai, 200040, China 中国上海市延安西路65号上海国际贵都大饭店办公楼405单元

Phone: +86-21-62489820

Fax: $+86-21-62489821$ 
(C) 2012 The Author(s). Licensee IntechOpen. This is an open access article distributed under the terms of the Creative Commons Attribution 3.0 License, which permits unrestricted use, distribution, and reproduction in any medium, provided the original work is properly cited. 